\title{
Adoption Determinants of Modern Rice Cultivars among Smallholders of Northern Iran
}

\author{
Dariush Ashoori ${ }^{1, *} \mathbb{C}$, Mohammad Sadegh Allahyari ${ }^{2,3} \mathbb{C}$, Asghar Bagheri $^{1}$ and \\ Christos A. Damalas 4 (iD \\ 1 Faculty of Agriculture and Natural Resources, University of Mohaghegh Ardabili, 56199-11367 Ardabil, Iran; \\ bagheri_a2001@yahoo.com \\ 2 Department of Agricultural Management and Development, Rasht Branch, Islamic Azad University, \\ 41476-54919 Rasht, Iran; allahyari@iaurasht.ac.ir \\ 3 Faculty of Economic and Management Sciences, North-West University, 2745 Mmabatho, South Africa \\ 4 Department of Agricultural Development, Democritus University of Thrace, 68200 Orestiada, Greece; \\ cdamalas@agro.duth.gr \\ * Correspondence: dariushashoori@ymail.com
}

Received: 13 September 2019; Accepted: 21 October 2019; Published: 24 October 2019

\begin{abstract}
Several agronomic innovations and precision technologies have been developed and disseminated in rice cultivation, but adoption is often lagged, particularly in developing countries. The objective of this work was to collect information on the use of improved rice cultivars and factors affecting adoption through a farmers' survey in Guilan Province, northern Iran. About 4 out of 10 farmers (42.8\%) used improved rice cultivars. Above half of the farmers $(55.2 \%)$ recognized the high profitability of this technology and half $(49.8 \%)$ realized that modern rice cultivars are of great importance. However, there were some farmers who perceived no profitability $(14.8 \%)$ or no importance $(12.5 \%)$ regarding this technology. Additionally, 9.8\% were not aware of the profitability, and $16.2 \%$ were not aware of the importance of the technology. The majority of the farmers $(60.5 \%)$ collaborated with fellow farmers about common production problems. Nevertheless, low cooperation with extension agents was noted for $58.5 \%$ of the farmers and low attendance of local agricultural offices activities was noted for $59.8 \%$ of the farmers. A logistic regression analysis showed that perceived profitability and perceived importance of modern varieties, background in rice farming, and size of livestock holdings were positively associated with the adoption of improved cultivars. It can be concluded that the low acceptance of modern rice cultivars in the study area is related to current farming socio-economic conditions. Dissemination of information on improved cultivars from experienced farmers to other farmers should be considered to promote adoption, along with financial incentives to low-income farmers.
\end{abstract}

Keywords: importance; profitability; seeds; technology adoption

\section{Introduction}

Rice (Oryza sativa L.) is a major crop in Iran along with wheat and barley. Based on statistics of the Ministry of Jihad-e-Agriculture of Iran, the country produced about 2.7 million metric tonnes of rice in 2011 [1]. Rice is mainly produced in the northern part of Iran near the Caspian Sea. More than $80 \%$ of the rice belt is spread in the provinces of Mazandaran and Guilan. Guilan Province is the most important province in this regard, followed by Mazandaran Province and much smaller areas in the rest of the country [2]. Despite the low productivity of local varieties (ranging between 2.5 to $3.5 \mathrm{t} / \mathrm{ha}$ ), more than $80 \%$ of the total rice area in Iran is cultivated with these varieties owing to their high-quality traits (i.e., long slender grain, head rice recovery of $60 \%$ to $63 \%$, intermediate amylose 
content, aroma, and elongation qualities). From an agronomic point of view, local rice varieties are characterized by tall stature, weak culms, and droopy leaves. Moreover, they are prone to lodging and susceptible to rice blast (Magnaporthe oryzae) and rice stem borer (Chilo suppressalis). Local rice varieties have been cultivated for a long time in various regions of Iran and have adapted to different environmental conditions over the years due to their relatively large diversity [3].

The adoption of new agricultural technologies can boost production and thus improve farmers' income [4-7]. However, new technologies often take time to disseminate among rural communities due to farmers' lack of awareness as well as lack of promotion [8,9]. Rice cultivation in the northern areas of Iran has a long history, with a significant part of the rice fields being cultivated with local varieties owing to their high quality characteristics [10]. However, low yields, lodging, and susceptibility to pests often limit production. Therefore, using new technologies could enhance return per unit area [11,12]. However, farmers tend to assess a technology with different criteria and objectives than those considered by scientists. Therefore, farmers may be reluctant to accept new technologies because of various obstacles, which will slow adoption [4]. Thus, understanding farmers' preferences is important for the successful adoption of improved rice varieties.

Different factors can influence technology adoption among farmers, especially the adoption of modern cultivars. Previous research in Pakistan [13,14], Nepal [15], southwestern Nigeria [16], and Ghana [17] showed that education, land size, land ownership, land area under cultivation, farming experience, connection with extension services, and characteristics of the varieties favored the acceptance of improved varieties of different crops. On the other hand, the high price of seeds, low product quality of the modern cultivars, low profitability compared with local cultivars, high demands of inputs (e.g., water and fertilizer), and sensitivity to common plant pathogens negatively impacted the adoption of modern cultivars [18]. Moreover, seed availability was reported as a significant barrier in the increase of rice production in western Niger [19]. Farmers' perceptions of yield and risk of improved maize cultivars affected adoption in central Cameroon [20]. Structural barriers that make improved cassava varieties less profitable for the poor need to be overcome to reduce poverty in Nigeria [21]. In Uganda, recent research on the adoption of drought-tolerant maize varieties identified gaps in potential adoption due to a lack of awareness as well as poor access to seeds and high seed prices [22]. Access to the market and contact with extension services promoted the adoption process of improved chickpea varieties in Ethiopia [23].

Increasing yield per unit area is a main target for increasing rice production, given the barriers to the expansion of cultivated lands in the study area (Guilan Province). In this sense, the acceptance of modern varieties can be promising. From an agronomic point of view, modern varieties typically have robust genotypes that are the outcome of breeding efforts for high yield and stable productivity under diverse growth conditions (e.g., stress imposed by diseases and insect pests, or abiotic stresses such as extreme water or temperature conditions). The development of modern cultivars is an essential aspect of sustainable cropping systems, as they can lead to land-saving, conservation of natural resources through their interaction with input use and through their impact on biodiversity, and benefits to poor farmers in marginal areas through the low prices of produce and increased opportunities for employment [24]. In addition, system stability in the face of external shocks is often used as a measure of sustainability. However, the acceptance of improved varieties is always affected by the process of transfer to farmers. Thus, solutions need to start by understanding farmers' needs and perspectives, so that specific barriers to technology uptake are well understood before policy solutions can be designed. This includes understanding, for instance, whether the primary binding constraint is a lack of information about agricultural technologies or poor-quality inputs and technologies.

In this study, we used the "farm structure model" based on the idea that larger and wealthier farms are more likely to have the economic flexibility to adopt innovations [25]. This model states that farmers must make economic choices in their day-to-day production decisions. Based on this model, farmers face three major types of constraints in their choices: economic, technological, and institutional. Therefore, they need to determine how to use land, inputs, and technologies in their economic profit 
calculations [26]. The farm structure model emphasizes profitability as well as economic incentives for innovation adoption, while farmers' ability to bear the risk involved in trying an innovation is also an important determinant of adoption. According to the rationale of this model, the existence of these incentives increases the profitability and consequently the acceptance of an innovation. An assumption of the model is that acceptance behavior is initially subordinate to the ability to act on innovation, and that the acceptance of innovation is limited by the lack of economic resources. Another assumption of the model is that individuals are unable to adopt technologies because they do not have the financial resources to operate them. The farm structure model states that the most important limiting factors for the adoption of innovations are access to capital and land [27], while the role of information and attitude factors has received less attention [28].

As already explained above, understanding the factors affecting the adoption of modern cultivars is essential for shaping appropriate policy measures to improve the livelihoods of smallholders following the assumptions of the farm structure model. By identifying what factors affect adoption, it is possible to identify how to induce adoption among non-adopters. Thus, the objective of this work was to highlight the drivers of the use of modern varieties among rice growers in Guilan Province, Iran.

\section{Materials and Methods}

\subsection{Study Area and Sample Selection}

Farmers of Rudsar County of northern Iran (Guilan Province) were selected for the study. All rice farmers living in the county were considered, irrespective of the adoption of improved varieties. The smallest sample size was determined to be 370 people according to Bartlett et al. [29], but an extra $10 \%$ was added to avoid non-response errors. The survey was conducted in 2015.

\subsection{Data Collection}

Data were collected on the basis of a questionnaire that was developed after a literature review $[15,18,19]$. The questionnaire assessed the adoption of improved varieties (non-adoption $=0$, adoption $=1$ ) as the dependent variable and various attributes as the independent variables. Among the independent variables, profitability referred to the capability of generating profits from the use of modern cultivars, while importance referred to adaptability, stability, and productivity of these cultivars under diverse growth conditions, reflecting farmers' level of necessity of this material. Independent variables were assessed with a 5-point scale: very low $(=1)$, low $(=2)$, moderate $(=3)$, high $(=4)$, and very high $(=5)$. The content validity of the research tool was tested by experts in agricultural extension and agronomy from the Jihad-e-Agriculture Organization. Before the study, a pilot study was conducted with 30 participants outside the study sample to assess the reliability of the questionnaire. Cronbach's alpha was 0.91 , which indicated good internal consistency of the questionnaire. Face-to-face interviews were conducted for data collection, with participants being recruited using simple random sampling based on farmers' lists from the local authorities.

\subsection{Data Analysis}

Descriptive statistics were calculated for the independent and dependent variables. The independent $t$-test (for continuous variables) and Mann-Whitney test (for ordinal variables) were used to compare characteristics of adopters and non-adopters. In addition, logistic regression was implemented to determine the association of the independent variables with the adoption of the modern varieties. Logistic regression was used because of the dichotomous nature (no, yes) of the dependent variable. The independent variables in the model included perceived profitability and perceived importance (i.e., necessity) of the modern varieties, social participation of growers, demographic data, economic data, and technical data (related to farm structure). In statistical model building, it is common to minimize variables until the most parsimonious model fits the data, which also results in numerical stability and generalizability of the results; therefore, the backward stepwise selection 
approach was used. Data analysis was performed using Statistical Package for the Social Sciences (SPSS Inc, Chicago, USA).

\section{Results}

\subsection{Farmer Profile}

Participant ages ranged from 25 to 80 years, with a mean age of 51.26 (Table 1). Most farmers were in the age group of $40-50$ years. Almost one-third of the farmers $(31.5 \%)$ had a university degree and $26.2 \%$ had graduated high school. Nevertheless, the greatest part $(40.0 \%)$ had primary or medium education, and a small fraction $(2.3 \%)$ were illiterate. Farmers had variable experience in rice cultivation from 5 to 65 years with a mean of 29.73 years. Most farmers (34.2\%) were in the category of 20-30 years of experience.

Table 1. Demographic features of rice growers in Rudsar County $(n=400)$.

\begin{tabular}{ccccc}
\hline Variable & Frequency & Percentage (\%) & Mean & SD \\
\hline Age (years) & 58 & 14.5 & 51.26 & 10.872 \\
$<40$ & 182 & 45.5 & & \\
$40-50$ & 78 & 19.5 & - \\
$51-60$ & 82 & 20.5 & \\
$\geq 60$ & & & & \\
Education level & 9 & 2.3 & \\
Illiterate & 160 & 40.0 & \\
Elementary and intermediate & 105 & 26.2 & \\
schools & 126 & 31.5 & \\
High school and diploma & & & \\
Academic education & 131 & 32.8 & \\
Experience in rice farming (years) & 137 & 34.2 & \\
$<20$ & 44 & 11 & \\
$20-30$ & 88 & 22 & \\
$31-40$ & & & \\
$\geq 40$ & & &
\end{tabular}

Most farmers did not have livestock, but the average livestock of the farmers in the sample was 4.23 heads (Table 2). Moreover, most farmers were in the agricultural income group of $<50$ million Iranian rials (IRR) and non-agricultural income group of $<50$ million IRR. Rice production averaged $2153.25 \mathrm{~kg} /$ year. Farmers in the sample had an average of 48,632,500 IRR agricultural expenses and most were in the group of $>30$ million IRR. The average farm area was calculated to $1.60 \mathrm{ha}$, but most farmers $(67.2 \%)$ had farm area $<1$ ha (Table 3$)$. The highest proportion $(53.0 \%)$ was associated to $>3$ field plots. The average distance of the household from farm was $2.10 \mathrm{~km}$, but most households $(52.5 \%)$ were within a distance of $<1 \mathrm{~km}$ and few $(17.4 \%)$ were within a distance of $>3 \mathrm{~km}$. The average distance of the household from the road was $0.92 \mathrm{~km}$. For most farmers $(56.2 \%)$ the distance of the household from the road ranged between 0.1 and $1 \mathrm{~km}$. 
Table 2. Economic aspects of rice growers in Rudsar County $(n=400)$.

\begin{tabular}{|c|c|c|c|c|}
\hline Feature & Frequency & Percentage $(\%)$ & Mean & SD \\
\hline Number of livestock (heads) & & & 4.23 & 7.289 \\
\hline 0 & 240 & 60.0 & & \\
\hline $1-10$ & 98 & 24.5 & & \\
\hline$>10$ & 62 & 15.5 & & \\
\hline Number of poultries (hens) & & & 24.46 & 53.478 \\
\hline 0 & 144 & 36.0 & & \\
\hline $1-20$ & 128 & 32.0 & & \\
\hline $21-40$ & 76 & 19.0 & & \\
\hline$>40$ & 52 & 13.0 & & \\
\hline Agricultural income (million IRR) & & & $117,557,500$ & $105,674,165.56$ \\
\hline$<50$ & 159 & 39.8 & & \\
\hline $50-100$ & 108 & 27.0 & & \\
\hline$>100$ & 133 & 33.2 & & \\
\hline Non-agricultural income (million IRR) & & & $91,350,000$ & $103,998,397.42$ \\
\hline 0 & 72 & 18 & & \\
\hline$<50$ & 122 & 30.5 & & \\
\hline $50-100$ & 116 & 29 & & \\
\hline$>100$ & 90 & 22.5 & & \\
\hline Rice production rate $(\mathrm{kg} /$ year$)$ & & & 2153.25 & 1483.236 \\
\hline$<1500$ & 169 & 42.2 & & \\
\hline $1500-3000$ & 177 & 44.2 & & \\
\hline$>3000$ & 54 & 13.5 & & \\
\hline Total agricultural expenses (million IRR) & & & $48,632,500$ & $52,430,284.96$ \\
\hline$<15$ & 116 & 29 & & \\
\hline $15-30$ & 93 & 23.2 & & \\
\hline$>30$ & 191 & 47.8 & & \\
\hline
\end{tabular}

IRR: Iranian rials (at the time of the study 1 USD was equal to 28,000 Iranian rials).

Table 3. Technical aspects of rice growers in Rudsar County $(n=400)$.

\begin{tabular}{ccccc}
\hline Features & Frequency & Percentage (\%) & Mean & SD \\
\hline Land size (ha) & & & & \\
$<1$ & 269 & 67.2 & 1.60 & \\
$1-2$ & 68 & 17.0 & & \\
$>2$ & 63 & 15.8 & & \\
Number of farm parcels & & & & \\
1 & 106 & 26.5 & & \\
2 & 56 & 14.0 & & \\
3 & 26 & 6.5 & \\
$>3$ & 212 & 53.0 & & \\
House distance to farm $(\mathrm{km})$ & & & \\
$<1$ & 210 & 52.5 & \\
$1-3$ & 120 & 30.0 & \\
$>3$ & 70 & 17.5 & & \\
House distance to road $(\mathrm{km})$ & & & & \\
$<0.1$ & 93 & 23.2 & 0.92 \\
$0.1-1$ & 225 & 56.2 & & \\
$>1$ & 82 & 20.5 & & \\
\hline
\end{tabular}

High levels of cooperation with colleague farmers, with Dehyari (local municipality), and with rural entities and cooperatives were noted among participants (Table 4). Nevertheless, there was low participation in Jihad-e-Agriculture programs and poor collaboration with extension services. It is noted that $59.8 \%$ of the farmers had very low or low participation in Jihad-e-Agriculture programs and a similar proportion had very low or low co-operation with extension agents. 
Table 4. Social participation of rice growers in Rudsar County $(n=400)$.

\begin{tabular}{|c|c|c|c|c|c|c|c|}
\hline Social Participation & VL & $\mathbf{L}$ & $\mathbf{M}$ & $\mathbf{H}$ & VH & \multirow{2}{*}{ Mean } & \multirow{2}{*}{ SD } \\
\hline & \multicolumn{5}{|c|}{ Percentage (\%) } & & \\
\hline $\begin{array}{l}\text { Cooperation with other farmers about } \\
\text { production problems }\end{array}$ & 2.0 & 8.5 & 29.0 & 28.5 & 32.0 & 3.80 & 1.045 \\
\hline $\begin{array}{c}\text { Cooperation with Dehyari and Islamic Council } \\
\text { of village }\end{array}$ & 10.0 & 7.0 & 28.5 & 30.0 & 24.5 & 3.52 & 1.218 \\
\hline $\begin{array}{l}\text { Membership and cooperation with rural } \\
\text { entities and cooperatives }\end{array}$ & 8.3 & 19.0 & 21.2 & 35.0 & 16.5 & 3.32 & 1.195 \\
\hline $\begin{array}{l}\text { Attendance in } \\
\text { educational-promotional courses }\end{array}$ & 18.5 & 18.0 & 34.0 & 23.8 & 5.7 & 2.80 & 1.63 \\
\hline $\begin{array}{l}\text { Cooperation in programs recommended by } \\
\text { Jihad-e-Agriculture }\end{array}$ & 36.2 & 23.6 & 12.2 & 19.5 & 8.5 & 2.40 & 1.368 \\
\hline Cooperation with extension agents & 51.5 & 7.0 & 20.0 & 15.3 & 6.2 & 2.18 & 1.345 \\
\hline
\end{tabular}

VL: very low, L: low, M: moderate, H: high, VH: very high.

\subsection{Utilization of Improved Cultivars}

Most farmers (57.2\%) did not adopt the technology of improved cultivars-this technology was adopted by $42.8 \%$ of the respondents. Nevertheless, about half of the farmers (55.2\%) perceived the improved cultivars as highly profitable and half of the farmers $(49.8 \%)$ perceived them as highly important (Table 5). The most convenient information source among the rice farmers surveyed was information from other farmers (mean $=2.95)$, followed by TV and radio (mean $=2.51$ ), while extension agents, education movies, and research centers showed low mean values (1.60, 1.59, and 1.28, respectively) (Table 6).

Table 5. Perceived profitability and perceived importance of improved cultivars among rice growers of Rudsar County $(n=400)$.

\begin{tabular}{cccccccc}
\hline \multirow{2}{*}{ High-Yield Rice Cultivars } & \multicolumn{4}{c}{ Percentage (\%) } & \multirow{2}{*}{ Mean } & \multirow{2}{*}{ SD } \\
\cline { 2 - 7 } & Do Not Know & None & Low & High & Very High & & \\
\hline Perceived profitability & 9.8 & 14.8 & 20.2 & 41.2 & 14.0 & 1.60 & 0.937 \\
Perceived importance & 16.2 & 12.5 & 21.5 & 36.0 & 13.8 & 2.61 & 0.931 \\
\hline
\end{tabular}

Table 6. Usefulness of information sources among rice growers of Rudsar County $(n=400)$.

\begin{tabular}{ccc}
\hline Information Source & Mean & SD \\
\hline Farmers & 2.95 & 0.974 \\
TV and radio & 2.51 & 1.014 \\
Extension agents & 1.60 & 1.494 \\
Educational movies & 1.59 & 1.374 \\
Research centers & 1.28 & 1.360 \\
Internet & 1.14 & 1.405 \\
\hline
\end{tabular}

\subsection{Differences between Adopters and Non-Adopters of Improved Cultivars}

Adopters of improved cultivars perceived higher importance and profitability of improved cultivars and had higher social participation than non-adopters (Table 7). Moreover, adopters were slightly older and had lower education than non-adopters. Adopters were more experienced farmers, had greater number of livestock and poultries, higher agricultural income, and greater number of land parcels than non-adopters (Table 7). 
Table 7. Differences between adopters and non-adopters of improved cultivars among rice growers of Rudsar County ( $t$-test and Mann-Whitney test).

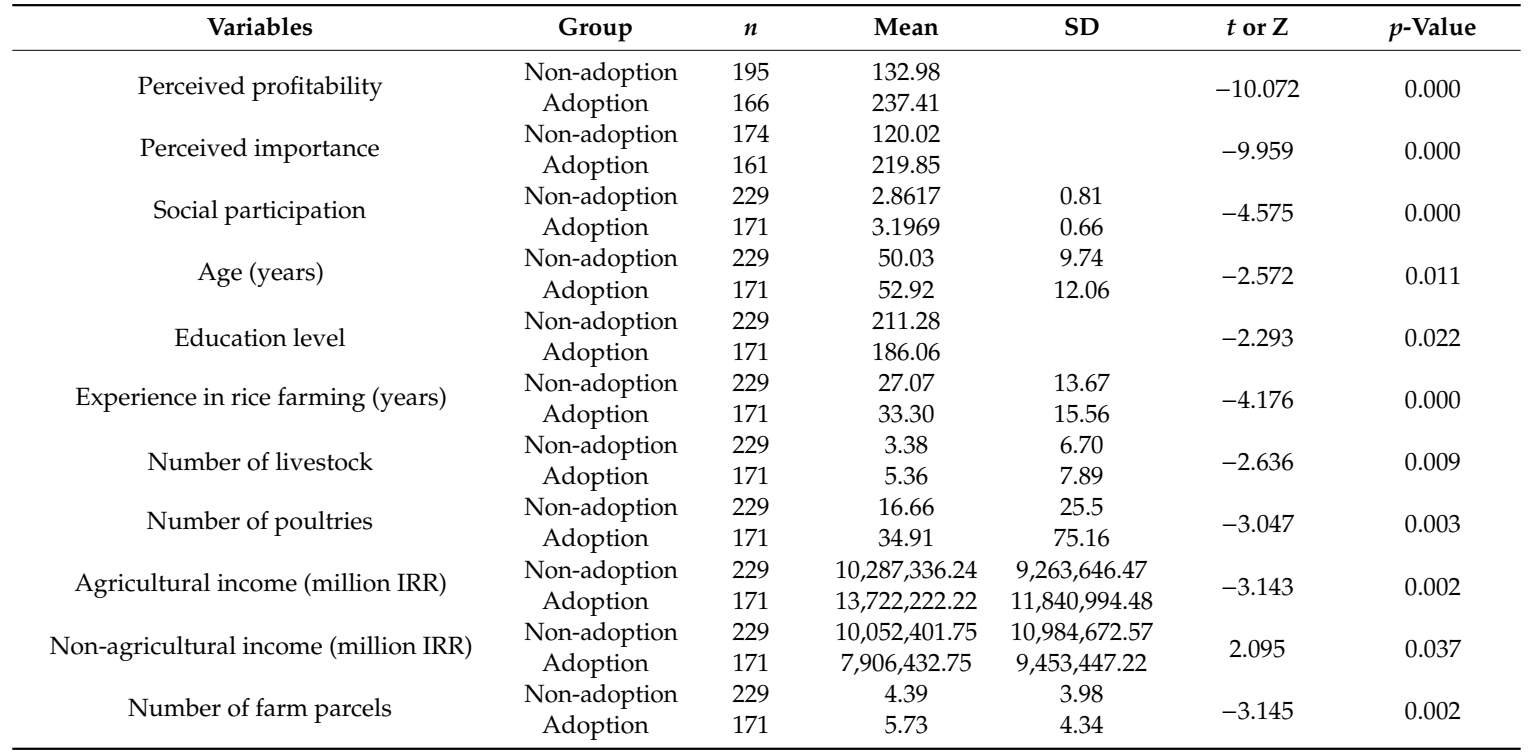

\subsection{Logistic Regression Analysis}

The logistic regression model showed high fit to the data with correct prediction $81.0 \%$ (Table 8 ), indicating the capability of the model to predict a high level of the amount of variance of the dependent variable. Perceived profitability and perceived importance of the improved varieties, background in rice cultivation, and size of livestock were positively associated with the adoption. Experience in rice cultivation, perceived importance, and perceived profitability of the improved varieties shared the maximum contribution in the prediction of adoption according to Wald values (Table 8). Perceived profitability showed the greatest contribution in forecasting adoption according to $\operatorname{Exp}(B)$ (i.e., the exponentiation of the B coefficient) odds ratio values.

Table 8. Technical factors affecting the adoption of improved cultivars among rice growers of Rudsar County.

\begin{tabular}{ccccccc}
\hline Variables & B & SE & Wald & $p$-Value & & Exp (B) \\
\hline Perceived profitability & 1.15 & 0.25 & 21.50 & 0.000 & $* *$ & 3.170 \\
Perceived importance & 1.08 & 0.22 & 24.06 & 0.000 & $* *$ & 2.940 \\
Experience in rice farming & 0.06 & 0.01 & 26.06 & 0.000 & $* *$ & 1.060 \\
Number of livestock & 0.05 & 0.02 & 5.86 & 0.015 & $*$ & 1.050 \\
Constant & -6.96 & 0.77 & 81.52 & 0.000 & $* *$ & 0.001 \\
\hline
\end{tabular}

$-2 \log$ likelihood = 286.070; Cox \& Snell $\mathrm{R}^{2}=0.406$; Nagelkerke $\mathrm{R}^{2}=0.542 ;{ }^{* *}$ Significant at $p<0.01$; $^{*}$ significant at $p<0.05$; Correct prediction $=81.0 \%$.

\section{Discussion}

This study determined drivers of the adoption of modern rice cultivars among smallholders of northern Iran, for which no relevant data exist in the literature. Significant relationships between the use of modern rice cultivars and several independent variables were identified with logistic regression analysis. Perceived profitability and perceived importance of improved seeds, background in rice farming, and livestock holdings were positively associated with the adoption of improved cultivars. Today, farmers, advisors, and policy makers face a wide range of technologies with uncertainties in the agri-food chain which they must deal with. Therefore, our findings assist in better understanding the adoption of this technology and thus may be important for seed delivery systems, pointing to policies for promoting acceptance of modern cultivars among non-adopters. The novelty of this research stems 
from the paucity of data in the literature on modern cultivar adoption concerning rice, as very few studies have assessed the adoption of modern rice cultivars, while no study has identified factors affecting the adoption of modern rice cultivars in Guilan Province, a major rice producing-province of Iran. Moreover this study provides a detailed regional representation of farmers included in the project, based on well-established data sources. Therefore, it adds useful information on the adoption of modern rice cultivars in the study area, and by identifying what factors affect adoption, one can determine how to induce the adoption of modern cultivars among non-adopters.

The perceived profitability of the technology was positively associated with the acceptance of modern rice cultivars $(p<0.01)$, in agreement with previous literature $[30,31]$, which showed that stating the advantages and benefits of modern technologies to rice growers can encourage their use. A technology is useful to the extent that it improves production and profit, and it is applied to the extent that it generates and satisfies users' needs. Economic profitability is a crucial factor before farmers make adoption decisions [32]. Therefore, a lag in the spread of improved seeds use could be due to the perception of low profitability among farmers $[33,34]$. Other studies have shown that the adoption of different technologies was favored by positive perceptions of profitability of each technology among farmers $[35,36]$. Additionally, doubts about the benefits of variable fertilization rate among grain growers of Western Australia hindered adoption of the technology [37]. In our study, the perceived importance of improved seeds favored the adoption of modern cultivars $(p<0.01)$, showing that technologies that are tailored to farmers' needs are more likely to be accepted. The importance and usefulness of the technology have been reported to be significant determinants of the adoption of a technology in previous studies [38,39]. From this point of view, research centers should determine farmers' needs and provide technologies that are more interesting to them.

The adoption of improved varieties was positively favored by rice cultivation experience $(p<0.01)$, as also reported elsewhere $[15,40,41]$. Similarly, the adoption of current technology in rice management in India was constrained by lack of experience [42]. Farming experience reflects knowledge that farmers have gained, and can be used to tackle farm production problems [33]. Farming experience can play an important role early in the adoption because the advantages of the technology are still being assessed. From this point of view, to promote adoption there is a need for progressive growth of the technology and constant farmer training [43]. This finding is rational, as experienced farmers are generally more competent with better access to necessary information about modern technologies, implying that accumulated knowledge may help in better evaluating information and thus impacting adoption decision [40]. It is noteworthy that apart from solely being adopters, farmers are involved in the generation of innovations [44].

The adoption of modern cultivars was positively associated with number of livestock $(p<0.05)$; that is, farmers with large number of livestock were more willing to adopt the improved varieties. In agreement with the current finding, a previous study reported that owning oxen favored the probability of adopting modern varieties [45]. It seems that animal power is a significant factor in small cropped areas because it is available for plowing where tractor mechanization does not exist or perhaps is unprofitable. Moreover, livestock can be a source of off-farm income that can be exploited for supplying farming inputs. Livestock shows opportunity of working capital for farming tasks [46]. From this point of view, livestock can contribute to the diversification of income sources, and can thus allow the reallocation of other resources for improving farm productivity [47]. However, it is also possible that farmers with income from livestock may be reluctant to accept a new technology unless non-farm alternatives are more rewarding to them $[35,48]$. Additionally, the number of livestock held likely affects access to animal manure and hence soil fertility. From this point of view, the number of livestock may also be a proxy for wealth, and hence can increase farmers' capacity to bear the risk of trying a new cultivar. However, smaller and poorer farmers operating on less-favorable plots may correctly perceive that the new cultivars are not more profitable for them and thus that the new technology is "not important" for addressing their most pressing constraints, which could vary from 
labor availability at peak periods of the production cycle for the new varieties to access to finance for inputs.

The current study also showed that adopters had significantly higher agricultural income and greater number of parcels than non-adopters. Farm income promotes technology adoption by overcoming the credit constraints of rural households in developing countries [49]. Farm income offers liquid capital to farmers, thus enhancing capacity for purchase of inputs such as improved seed and fertilizers. It is likely that a great number of plots may allow for some kind of experimentation with the new technology by spreading out risk. In this context, the new technology, as developed by the researchers in the study area, may be suitable for only a subset of the farmers in the area (e.g., those who are wealthier and on more favorable plots). This problem seems to lie in the technology, not necessarily in those who do not adopt, as farmers who do not adopt may be acting very rationally given their circumstances. This point was made in much of the farming systems research of the 1970s and 1980s, when researchers at CIMMYT (International Maize and Wheat Improvement Center) developed the notion of "recommendation domains" for different types of technology (i.e., tailoring different products for different groups of farmers, even farmers living in the same area) [50].

\section{Conclusions}

This work highlighted drivers of the adoption of improved rice varieties among farmers of Guilan Province. Farmers in the study area are expected to use improved rice varieties in their fields if they perceive that the investment is important and will be profitable. On the other hand, low adoption seems likely to be connected with the inconsistency of the modern varieties with current farming socio-economic conditions. Where benefits from the adoption of sustainable technologies are expected to accrue only to people outside agriculture and where there are no markets for the benefits of those technologies, the levels of adoption could be sub-optimal. Based on the findings of this study, the most likely way to convince farmers to accept an innovation is the provision of basic information about the advantages of the technology through extension services, demonstration projects, participatory research, and close cooperation with other farmers. Using experienced farmers for information transfer to other farmers should be considered to promote adoption, along with financial incentives to low-income farmers. It is possible that tailoring different modern varieties to different groups of farmers would be required, as there may be a range of different recommendation domains. Appropriate policies facilitating the adoption of improved varieties, such as incentives, subsidies, or price supports as well as growth of the number of people involved in extension and their quality, could be put forth according to findings. Nevertheless, it should be kept in mind that while such incentives may be appropriate in the short term to mitigate the risk associated with adoption and to help farmers learn more about the technologies by trying them out, they may not be a financially sustainable strategy in the long run, as the budgetary costs of such measures can be high.

Author Contributions: D.A. conducted the survey, gathered data, and analyzed data; M.S.A. conceived the idea, planned the research, analyzed data, interpreted data, and wrote the article; A.B. contributed to data interpretation and edited the article; C.A.D. contributed to data interpretation and edited the article. All authors approved the final version of this article.

Funding: This research received no external funding.

Conflicts of Interest: The authors declare no conflicts of interest.

\section{References}

1. Kazemi, H.; Kamkar, B.; Lakzaei, S.; Badsar, M.; Shahbyki, M. Energy flow analysis for rice production in different geographical regions of Iran. Energy 2015, 84, 390-396. [CrossRef]

2. Fahmideh, S.N.; Allahyari, M.S.; Damalas, C.A.; Masouleh, Z.D.; Ghazi, M. Predicting adoption of double cropping in paddy fields of northern Iran: A comparison of statistical methods. Paddy Water Environ. 2017, 15,907-917. [CrossRef] 
3. Tarang, A.; Hosseini, M. Evaluation of molecular diversity of different Hashemi rice varieties of north of Iran using microsatellite markers. J. Manag. Syst. 2017, 7, 17-31.

4. Mariano, M.J.; Villano, R.; Fleming, E. Factors influencing farmers' adoption of modern rice technologies and good management practices in the Philippines. Agric. Syst. 2012, 110, 41-53. [CrossRef]

5. Rimal, N.S.; Kumar, S.; Chahal, V.P.; Singh, V. Impact of adoption of improved varieties of chikpea (Cicer arietinum) on yield and income in Madhya Pradesh. Indian J. Agric. Sci. 2015, 85, 555-560.

6. Villano, R.; Bravo-Ureta, B.; Solís, D.; Fleming, E. Modern rice technologies and productivity in the Philippines: Disentangling technology from managerial gaps. J. Agric. Econ. 2015, 66, 129-154. [CrossRef]

7. Askary Bozayeh, F.; Keshavarzshal, F.; MojibHaghghadam, Z.; Shahinrokhsar, P. Rice farmers' behaviors and attitudes toward agricultural extension programs in healthy food production (case of Lahijan and Amlash Counties, Northern Iran). Int. J. Agric. Manag. Dev. 2017, 7, 37-46.

8. Kalantari, A.; Khadem Adam, N. The Policy of Improving Nourishment Pattern, Physiology of Nourishment, and Food Economy, 2nd ed.; Agricultural Planning, Economic and Rural Development Research Institute: Tehran, Iran, 1997.

9. Simtowe, F.; Asfaw, S.; Abate, T. Determinants of agricultural technology adoption under partial population awareness: The case of pigeonpea in Malawi. Agric. Econ. 2016, 4, 7. [CrossRef]

10. Rani, N.S. The Rice Situation in Iran. International Rice Commission Newsletter; Food and Agriculture Organization of the United Nations: Rome, Italy, 1998; Volume 47.

11. Dinpanah, G.; Chizari, M.; Bardrageh, A. Factors affecting the technology adoption by wheat growers of Isfahan country. J. Agric. Sci. 2009, 3, 103-116.

12. Khonje, M.; Manda, J.; Alene, A.D.; Kassie, M. Analysis of adoption and impacts of improved maize varieties in Eastern Zambia. World Dev. 2015, 66, 695-706. [CrossRef]

13. Iqbal, M.; Bashir, A.; Farooq, U. Factors affecting the adoption of hybrid maize varieties in the irrigated Punjab. Int. J. Agric. Biol. 1999, 1, 149-151.

14. Chandio, A.A.; Yuansheng, J. Determinants of adoption of improved rice varieties in Northern Sindh, Pakistan. Rice Sci. 2018, 25, 103-110. [CrossRef]

15. Joshi, G.; Pandy, S. Effects of farmer's perception on the adoption of modern rice varieties in Nepal. In Proceedings of the Conference on International Agricultural Research for Development, Stuttgart, Hohenheim, 11-13 October 2005.

16. Saka, J.O.; Okoruwa, V.O.; Lawal, B.O.; Ajijola, S. Adoption of improved rice varieties among smallholder farmers in south-western Nigeria. World J. Agric. Sci. 2005, 1, 42-49.

17. Alhassan, A.; Salifu, H.; Adebanji, A.O. Discriminant analysis of farmers' adoption of improved maize varieties in Wa Municipality, Upper West Region of Ghana. SpringerPlus 2016, 5, 1514. [CrossRef]

18. Keshavarz, F.; Allahyari, M.S.; Azarmi Sahsari, Z.; Khayyati, M. Factors influencing the non-adoption of high-yield rice cultivars by farmers of Guilan Province. Agric. Ext. Educ. Res. 2010, 3, 99-112.

19. Sow, M.; Seck, P.A.; Maiga, I.M.; Laing, M.; Ortiz, R.; Ndjiondjop, M.N. Farmers' rice knowledge and adoption of new cultivars in the Tillabéry region of western Niger. Agric. Food Secur. 2015, 4, 5. [CrossRef]

20. Takam-Fongang, G.M.; Kamdem, C.B.; Kane, G.Q. Adoption and impact of improved maize varieties on maize yields: Evidence from central Cameroon. Rev. Dev. Econ. 2019, 23, 172-188. [CrossRef]

21. Wossen, T.; Alene, A.; Abdoulaye, T.; Feleke, S.; Rabbi, I.Y.; Manyong, V. Poverty reduction effects of agricultural technology adoption: The case of improved cassava varieties in Nigeria. J. Agric. Econ. 2019, 70 , 392-407. [CrossRef]

22. Simtowe, F.; Marenya, P.; Amondo, E.; Worku, M.; Rahut, D.B.; Erenstein, O. Heterogeneous seed access and information exposure: Implications for the adoption of drought-tolerant maize varieties in Uganda. Agric. Food Econ. 2019, 7, 15. [CrossRef]

23. Verkaart, S.; Mausch, K.; Claessens, L.; Giller, K.E. A recipe for success? Learning from the rapid adoption of improved chickpea varieties in Ethiopia. Int. J. Agric. Sustain. 2019, 7, 34-48. [CrossRef]

24. Byelee, D. Modern varieties, productivity, and sustainability: Recent experience and emerging challenges. World Dev. 1996, 24, 697-718. [CrossRef]

25. Ommani, A.R.; Chizari, M.; Salmanzadeh, C.; Faraj Allah Hosaini, J. Predicting adoption behavior of farmers regarding on-farm sustainable water resources management (SWRM): Comparison of models. J. Sustain. Agric. 2009, 33, 595-616. [CrossRef] 
26. Karami, E.; Rezaii Moghadam, K.; Ebrahimi, H.R. Predicting rainfall irrigation acceptance: Comparison of models. J. Sci. Technol. Agric. Nat. Res. 2006, 10, 71-89.

27. Ebrahimi, H.R.; Karami, E. Determinants of irrigation method selection: Application of the holistic model. J. Agric. Econ. Dev. 1999, 26, 141-168.

28. Karami, E. Models of soil conservation technology adoption in developing countries: The case of Iran. Iran Agric. Res. 1995, 14, 39-62.

29. Bartlett, J.E.; Kotrlik, J.W.; Higgins, C.C. Organizational research: Determining appropriate sample size in survey research appropriate sample size in survey research. Inf. Technol. Learn. Perform. J. 2001, 19, 43-50.

30. Nazemolsadat, S.; Kamkar Haghighi, A.; Sharifzadeh, M.; Ahmadvand, M. Adoption of long-term rain forecasts: The case of wheat growers of Fars Province. Iranian Agric. Ext. Educ. J. 2006, 2, 1-15.

31. Lashgarara, F.; Asadi, A. Analysis of factors underpinning the adoption of sustainable agriculture by wheat farmers in Lorestan Province. Iranian J. Agric. Sci. 2008, 39, 97-104.

32. Cary, J.W.; Wilkinson, R.L. Perceived profitability and farmers' conservation behavior. J. Agric. Econ. 1997, 48, 13-21. [CrossRef]

33. Amare, M.; Asfaw, S.; Shiferaw, B. Welfare impacts of maize-pigeonpea intensification in Tanzania. Agric. Econ. 2012, 43, 27-43. [CrossRef]

34. Minten, B.; Koru, B.; Stifel, D. The last mile(s) in modern input distribution: Pricing, profitability, and adoption. Agric. Econ. 2013, 44, 629-646. [CrossRef]

35. Amsalu, A.; De Graaff, J. Determinants of adoption and continued use of stone terraces for soil and water conservation in an Ethiopian highland watershed. Ecol. Econ. 2007, 61, 294-302. [CrossRef]

36. Daberkow, S.G.; McBride, W.D. Farm and operator characteristics affecting the awareness and adoption of precision agriculture technologies in the US. Prec. Agric. 2003, 4, 163-177. [CrossRef]

37. Robertson, M.J.; Llewellyn, R.S.; Mandel, R.; Lawes, R.; Bramley, R.G.V.; Swift, L.; Metz, N.; O'Callaghan, C. Adoption of variable rate fertiliser application in the Australian grains industry: Status, issues and prospects. Prec. Agric. 2012, 13, 181-199. [CrossRef]

38. García, C.G.M.; Dorward, P.; Rehman, T. Farm and socio-economic characteristics of smallholder milk producers and their influence on technology adoption in Central Mexico. Trop. Anim. Health Prod. 2012, 44, 1199-1211. [CrossRef]

39. Abdollahzadeh, G.; Damalas, C.A.; Sharifzadeh, M.S. Understanding adoption, non-adoption, and discontinuance of biological control in rice fields of northern Iran. Crop Prot. 2017, 93, 60-68. [CrossRef]

40. Idrisa, Y.L.; Ogunbameru, B.O.; Madukwe, M.C. Logit and Tobit analyses of the determinants of likelihood of adoption and extent of adoption of improved soybean seed in Borno State, Nigeria. Green J. Agric. Sci. 2012, 2, 37-45. [CrossRef]

41. Onumadu, F.N.; Osahon, E.E. Socio-economic determinants of adoption of improved rice technology by farmers in Ayamelum local government area of Anambra State, Nigeria. Int. J. Sci. Technol. Res. 2014, 3, 308-314.

42. Sita Devi, K.; Ponnarasi, T. An economic analysis of modern rice production technology and its adoption behaviour in Tamil Nadu. Agric. Econ. Res. Rev. 2009, 22, 341-347.

43. Ainembabazi, J.H.; Mugisha, J. The role of farming experience on the adoption of agricultural technologies: Evidence from smallholder farmers in Uganda. J. Dev. Stud. 2014, 50, 666-679. [CrossRef]

44. Busse, M.; Doernberg, A.; Siebert, R.; Kuntosch, A.; Schwerdtner, W.; König, B.; Bokelmann, W. Innovation mechanisms in German precision farming. Prec. Agric. 2014, 15, 403-426. [CrossRef]

45. Ghimire, R.; Huang, W.; Shrestha, R.B. Factors affecting adoption of improved rice varieties among rural farm households in Central Nepal. Rice Sci. 2015, 22, 35-43. [CrossRef]

46. Perz, S. Social determinants and land use correlates of agricultural technology adoption in a forest frontier: A case study in the Brazilian Amazon. Hum. Ecol. 2003, 31, 133-165. [CrossRef]

47. Langyintuo, A.S.; Mungoma, C. The effect of household wealth on the adoption of improved maize carieties in Zambia. Food Policy 2008, 33, 550-559. [CrossRef]

48. Thuo, M.W.; Bravo-Ureta, B.E.; Obeng-Asiedu, K.; Hathie, I. The adoption of agricultural inputs by smallholder farmers: The case of an improved groundnut seed and chemical fertilizer in the Senegalese Groundnut Basin. J. Dev. Areas 2014, 48, 61-82. [CrossRef] 
49. Reardon, T.; Stamoulis, K.; Pingali, P. Rural nonfarm employment in developing countries in an era of globalization. Agric. Econ. 2007, 37, 173-183. [CrossRef]

50. Norman, D.W.; Worman, F.D.; Siebert, J.D.; Modiakgotla, E. The Farming Systems Approach to Development and Appropriate Technology Generation; FAO: Rome, Italy, 1995.

(C) 2019 by the authors. Licensee MDPI, Basel, Switzerland. This article is an open access article distributed under the terms and conditions of the Creative Commons Attribution (CC BY) license (http://creativecommons.org/licenses/by/4.0/). 